\title{
ISOLASI DAN KARAKTERISASI PLANT GROWTH PROMOTING RHIZOBACTERIA DARI RIZOSFER KEBUN KARET RAKYAT
}

\section{Isolation and Characterization of Plant Growth Promoting Rhizobacteria from the Rizosphere of Folk Rubber Plantations}

\author{
Nova Wulandari ${ }^{1)}$ Mokhamad Irfan $^{2)}$, dan Robbana Saragih ${ }^{2)}$ \\ 1) Mahasiswa Program Studi Agroteknologi, Fapertapet UIN Suska Riau \\ ${ }^{2)}$ Dosen Program Studi Agroteknologi, Fapertapet UIN Suska Riau \\ Jl. H.R. Soebrantas No. 155 KM 15 Simp. Baru Panam Pekanbaru Riau. \\ E-mail : novawulandari871@gmail.com \\ E-mail : mokhamadirfan65@gmail.com
}

\begin{abstract}
Diversity of vegetation that grows on the ground will affect the number and type of microbes in the rhizosphere of folk rubber plantations. The purpose of this research is to know the population, genus, and biological activity of PGPR bacteria (IAA hormone producers, phosphate solvents and biocontrol agent) originating from the rhizosphere of folk rubber plantations. This research was conducted from March to May 2018 at the Laboratory of Pathology, Entomology and Microbiology Faculty of Agriculture and Animal Sciences, Islamic State University Sultan Syarif Kasim Riau and UPT Health and Environment Laboratory. This research used observation method by taking soil samples that are composted, and data are presented in descriptive form. The parameters observed in this research were soil $\mathrm{pH}$, bacterial population, characterization of PGPR bacteria includes macroscopic, microscopic, biochemical reaction test and PGPR bacterial biological activity (IAA test qualitatively, phosphate solvent test and in-vitro inhibitory test). The results showed that the $\mathrm{pH}$ of the soil obtained at a depth of $0-20 \mathrm{~cm}$ was 3.19 with a bacterial population of $1.06 \times 10^{6} \mathrm{CFU} / \mathrm{g}$ of soil. A total of 4 isolates were able to produce IAA hormones namely genus Bacillus sp.1, Bacillus sp.2, Bacillus sp.3 and Bacillus sp.5. A total of 2 isolates were able to dissolve fostat, namely genus Bacillus sp. 1 and Bacillus sp. 2 and 2 isolates were able to play a role as inhibitory power against Fusarium sp. namely the genus Bacillus sp. 4 and Bacillus sp.5. There were 5 isolates of PGPR bacteria that had different biological activity abilities, namely genus Bacillus sp.1, Bacillus sp.2, Bacillus sp.3, Bacillus sp.4 and Bacillus sp.5.
\end{abstract}

Keywords: Bacillus sp., Rubber Plantations, PGPR

\begin{abstract}
ABSTRAK
Keragaman vegetasi yang tumbuh di atas tanah akan mempengaruhi jumlah dan jenis mikroba yang ada di dalam rizosfer perkebunan karet rakyat. Tujuan penelitian ini adalah untuk mengetahui populasi, genus dan aktifitas biologi bakteri PGPR (penghasil hormon IAA, pelarut fosfat dan agen biokontrol) yang berasal dari rizosfer perkebunan karet rakyat. Penelitian ini telah dilaksanakan pada bulan Maret sampai Mei 2018 di Laboratorium Patologi, Entomologi dan Mikrobiologi Fakultas Pertanian dan Peternakan Universitas Islam Negeri Sultan Syarif Kasim Riau dan di UPT Laboratorium Kesehatan dan Lingkungan. Metode yang digunakan dalam penelitian merupakan metode observasi, yaitu dengan mengambil sampel tanah yang dikompositkan dan data disajikan dalam bentuk deskriptif. Parameter yang diamati yaitu $\mathrm{pH}$ tanah, populasi bakteri, karakterisasi bakteri PGPR meliputi makroskopis, mikroskopis, uji reaksi biokimia dan aktifitas biologi bakteri PGPR (Uji IAA secara kualitatif, uji pelarut fosfat dan uji daya hambat secara in-vitro). Hasil penelitian menunjukkan bahwa $\mathrm{pH}$ tanah yang didapatkan pada kedalaman 0-20 cm yaitu 3,19 dengan populasi bakteri $1,06 \times 10^{6} \mathrm{CFU} / \mathrm{g}$ tanah. Sebanyak 4 isolat mampu menghasilkan hormon IAA yaitu genus Bacillus sp.1, Bacillus sp.2, Bacillus sp.3 dan Bacillus sp.5. Sebanyak 2 isolat mampu melarutkan fostat yaitu genus Bacillus sp.1 dan Bacillus sp.2 dan sebanyak 2 isolat mampu
\end{abstract}


berperan sebagai daya hambat terhadap cendawan Fusarium sp. yaitu genus Bacillus sp.4 dan Bacillus sp.5. Ditemukan 5 isolat bakteri PGPR yang memiliki kemampuan aktifitas biologi yang berbeda yaitu genus Bacillus sp.1, Bacillus sp.2, Bacillus sp.3, Bacillus sp.4 dan Bacillus sp.5.

Kata Kunci: Bacillus sp, Kebun Karet, PGPR.

\section{PENDAHULUAN}

Akar tanaman merupakan habitat yang baik bagi pertumbuhan mikroba. Interaksi antara bakteri dan akar tanaman akan meningkatkan ketersediaan nutrien bagi keduanya. Rizosfer (daerah perakaran) merupakan habitat yang sangat baik bagi pertumbuhan mikroba karena akar tanaman menyediakan berbagai bahan organik yang umumnya menstimulir pertumbuhan mikroba (Sumarsih, 2003).

Tanah merupakan media tumbuh tanaman yang banyak mengandung mikroorganisme, diantaranya berkoloni di sekitar perakaran tanaman dan memiliki aktivitas yang menguntungkan bagi tanaman baik secara langsung maupun tidak langsung (Kafrawi dkk., 2015), melalui mekanisme simbiosis mutualisme. Mikroorganisme mendapat nutrisi dari eksudat tumbuhan sedangkan tumbuhan terlindungi dari infeksi patogen tular tanah, tanaman menjadi resisten terhadap kekeringan, unsur hara menjadi tersedia bagi tanaman dan mikroba dapat memacu pertumbuhan tanaman karena sebagian mikroba mampu menghasilkan hormon tumbuh IAA.

Plant Growth Promoting Rizobacteria (PGPR) adalah kelompok bakteri yang hidup di daerah perakaran tanaman. PGPR memiliki peran penting bagi tumbuhan, seperti sebagai pengendali biologi, produksi fitohormon, peningkatan ketersediaan hara melalui fiksasi nitrogen maupun pelarutan unsur hara tanah menjadi tersedia bagi tanaman (Aryantha dkk., 2004)

Pengaruh PGPR secara langsung dalam meningkatkan pertumbuhan tanaman terjadi melalui berbagai mekanisme, diantaranya fiksasi nitrogen bebas yang ditransfer ke dalam tanaman, produksi siderofor yang mengkhelat besi $(\mathrm{Fe})$ dan membuat $\mathrm{Fe}$ tidak tersedia bagi patogen, melarutkan mineral seperti fosfor dan sintesis fitohormon. Pengaruh tidak langsung dalam meningkatkan pertumbuhan tanaman terjadi melalui penekanan fitopatogen.
Populasi mikroorganisme di rizosfer umumnya lebih banyak dan beragam berbanding pada tanah nonrizosfer (Niswati dkk., 2008). Aktivitas mikroorganisme rizosfer dipengaruhi oleh eksudat yang dihasilkan oleh perakaran tanaman. Beberapa mikroorganisme rizosfer berperan dalam siklus hara dan proses pembentukan tanah, pertumbuhan tanaman, memengaruhi aktivitas mikroorganisme, serta sebagai pengendali hayati terhadap patogen akar (Simatupang, 2008). Secara umum, mikroorganisme dapat hidup baik pada kelembaban yang cukup, salah satunya yaitu pada perkebunan karet yang dicirikan oleh beragamnya tumbuhan yang tumbuh bersamaan dengan pohon karet, sehingga secara langsung mempengaruhi kelimpahan dan komposisi tumbuhan bawah (Jobsi, 2001).

Menurut Saraswati dkk., (2007) fungsi mikroorganisme di dalam tanah ada empat, yaitu sebagai penyedia unsur hara dalam tanah, perombak bahan organik dan mineralisasi bahan organik, memacu pertumbuhan tanaman dan sebagai agen hayati (pengendali hama dan penyakit tanaman). Mikroba tanah, memiliki banyak peran penting dalam daur unsur organik untuk kehidupan, seperti penghasil hormon IAA. Hormon IAA adalah auksin endogen yang berperan dalam perkembangan akar, menghambat pertumbuhan tunas samping, merangsang terjadinya absisi, serta berperan dalam pembentukan jaringan xylem dan floem (Silitonga dkk., 2008).

\section{METODE PENELITIAN}

\section{Waktu dan Tempat.}

Penelitian ini telah dilaksanakan pada bulan Maret - Mei 2018. Sampel tanah diambil dari rizosfer kebun Karet Rakyat Kampung Sei Mesiang Kecamatan Kuok Kabupaten Kampar.

\section{Bahan dan Alat.}

Bahan yang digunakan yaitu sampel tanah, $\mathrm{NaCl}$ fisiologis $85 \%$, kapas, plastik klip, alumunium foil, bahan pewarnaan gram bakteri, alkohol 90\%, L-tryptophan, NA (Merck), PDA 
(Merck), Media Pikovskaya, Reagen Salkowski dan aquades. Alat yang digunakan pada penelitian ini adalah inkubator, petridis, tabung reaksi, rak tabung reaksi, jarum Ose, spatula, bunsen, pipet volume, batang L, mikroskop, pipet mikro, colony counter, Magnetic stirrer, labu Erlenmeyer, autoclave, oven, gelas Beaker, $\mathrm{pH}$ meter, vortex, shaker, timbangan analitik, hot plate, kaca objek, laminar air flow, kamera, alat tulis dan bor tanah.

Isolasi dan karakterisasi PGPR dilakukan di Laboratorium Patologi, Entomologi dan Mikrobiologi (PEM) Fakultas Pertanian dan Peternakan Universitas Islam Negeri Sultan Syarif Kasim Riau. Identifikasi dilakukan di Unit Pelaksana Teknis (UPT) Laboratorium Kesehatan dan Lingkungan Dinas Kesehatan Provinsi Riau.

\section{Sampel}

Pengambilan sampel yang digunakan adalah dengan cara purposive sampling. Sampel diambil sebanyak 5 titik sebanyak $100 \mathrm{~g}$ sampel tanah/titik kemudian dikompositkan (Saraswati dkk., 2007). Setelah dikompositkan diambil 200 g sampel tanah. Sampel tanah diambil dari kebun karet rakyat berumur 13 tahun yang banyak gulmanya dari lapisan pada kedalaman 0-20 cm. Tanah dibersihkan dari seresah, kemudian bor tanah yang telah disiapkan dicuci menggunakan air bersih, disemprot dengan alkohol $70 \%$ dan air steril lalu, dikeringkan menggunakan tissu. Selanjutnya bor ditekan ke dalam tanah, lalu tanah yang berada dalam bor diambil menggunakan spatula. Sampel tanah yang diambil dimasukkan ke dalam plastik, ditutup rapat dan diberi label.

\section{Prosedur Penelitian}

Enumerasi. Metode yang digunakan untuk menghitung jumlah koloni adalah metode cawan hitung dengan teknik pengenceran berseri menggunakan larutan $\mathrm{NaCl}$ fisiologis steril $0,85 \%$. Sebanyak $10 \mathrm{~g}$ sampel tanah ditambahkan $90 \mathrm{ml} \mathrm{NaCl}$ fisiologis steril dan dihomogenkan dengan shaker pada kecepatan $100 \mathrm{rpm}$ selama 1 jam. Pengenceran dilakukan dari $10^{-1} 10^{-2}, 10^{-3}, 10^{-4}$ dan $10^{-5}$ ditanam menggunakan media padat Nutrient Agar (NA) dalam cawan petri sebanyak $0,5 \mathrm{~mL}$. Setiap pengenceran diulang dua kali atau duplo. Inkubasi cawan petri pada posisi terbalik selama $1 \times 24$ jam dengan suhu $37^{\circ} \mathrm{C}$.
Cawan yang dipilih dan dihitung adalah cawan petri yang mengandung koloni antara 30300. Jika tidak ada, maka dipilih yang mendekati 300. Rumus menghitung jumlah koloni adalah sebagai berikut (Omar dkk., 1996).

Jumlah koloni $/ \mathrm{mL}=\frac{1}{\text { Vol. Sampel }} \mathrm{X}$

$\frac{1}{\text { Faktor Pengenceran }} \mathrm{x}$ Jumlah koloni dalam cawan

Karakterisasi PGPR. Karakterisasi bakteri PGPR secara makroskopis meliputi bentuk koloni, elevasi koloni, permukaan koloni dan warna koloni. Indentifikasi spesies bakteri PGPR secara mikroskopis diawali dengan pewarnaan gram dan dilanjutkan dengan uji reaksi biokimia meliputi uji katalase, uji oksidase, uji motilitas dan uji fermentasi glukosa. Hasil uji reaksi biokimia disesuaikan dengan buku Bergey's Manual of Determinative Bacteriology untuk menentukan genus bakteri yang didapat.

\section{Aktifitas biologi PGPR.}

Uji Produksi IAA secara kualitatif. Isolat diuji secara kualitatif menggunakan reagen Salkowski. Isolat PGPR diinokulasikan pada media Nutrient Agar datar yang disuplementasi triptofan dengan konsentrasi $100 \mathrm{ppm}$ menggunakan teknik goresan $\mathrm{T}$. Kemudian diinkubasi pada suhu ruang selama 48 jam. Pereaksi Salkowski diteteskan pada isolat PGPR yang telah tumbuh di medium Nutrient Agar datar sampai merata. Selanjutnya isolat yang telah ditetesi pereaksi Salkowski disimpan dalam ruang gelap selama 30 menit. Hasil positif ditunjukkan dengan perubahan warna koloni isolat menjadi merah muda (Khalida dan Zulaika, 2015).

Uji Pelarutan Fosfat. Isolat bakteri ditumbuhkan pada media Pikovskaya dengan cara isolat bakteri diambil menggunakan jarum ose secara aseptis. Media tersebut diinkubasi selama 7 × 24 jam pada suhu $37{ }^{\circ} \mathrm{C}$. Koloni yang tumbuh dan mampu membentuk zona bening diindikasikan sebagai isolat yang mampu melarutkan fosfat. Diameter koloni dan zona bening diukur pada 7 x 24 jam (Karpagam and Nagalakshmi, 2014).

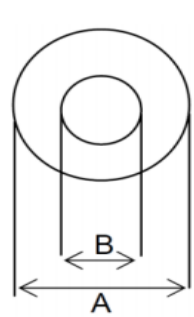

$$
\begin{aligned}
& \mathrm{IKF}=\frac{A}{B}=\frac{\text { Diameter Total }}{\text { Diameter Koloni }} \\
& \text { Keterangan: } \\
& \mathrm{A}=\text { Diameter total } \\
& \mathrm{B}=\text { Diameter koloni }
\end{aligned}
$$


Tabel 1. Kategori indeks zona bening

\begin{tabular}{ll}
\hline Indeks Zona Bening & Keterangan \\
\hline$\geq 1,59$ & Rendah \\
$1,6-2,12$ & Sedang \\
$2,15-2,59$ & Tinggi \\
$2,6-3$ & Sangat Tinggi \\
\hline
\end{tabular}

Sumber: Ruwandani dkk., (2014)

Uji daya hambat secara In-vitro. Pengujian in-vitro dilakukan untuk mengetahui kemampuan isolat dalam menghambat patogen (Fusarium sp) secara in-vitro. Uji antagonis dilakukan dengan cara oposisi langsung antara isolat dengan cendawan Fusarium sp dalam media PDA selama 5 hari (Kafrawi dkk., 2015). Persentase daya hambat (DH) isolat rizobakteri terhadap cendawan patogen ditentukan menggunakan rumus :

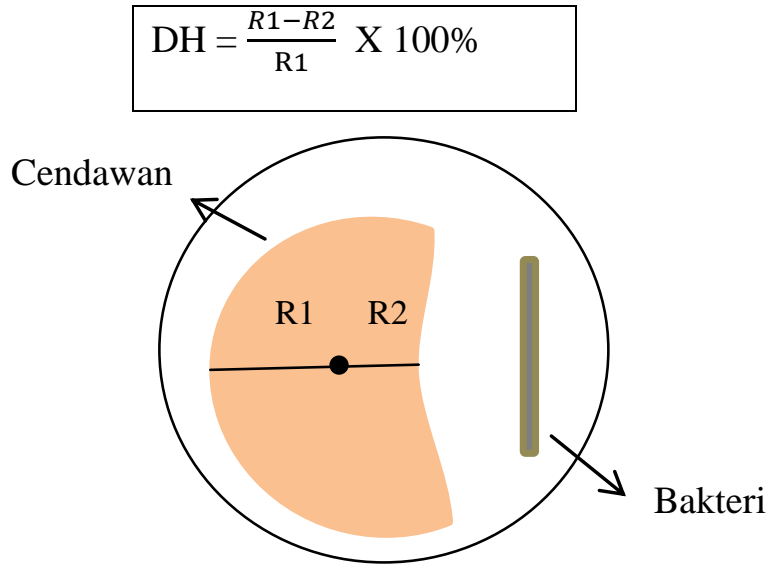

Gambar 1. Skema Pengukuran Uji Daya Hambat

\section{HASIL DAN PEMBAHASAN}

Enumerasi dan Karakterisasi. Hasil analisis pengukuran $\mathrm{pH}$ yang telah dilakukan didapatkan $\mathrm{pH}$ tanah pada kebun Karet Rakyat
Kab. Kampar pada kedalaman 0-20 $\mathrm{cm}$ yaitu 3,19 . Hal ini dikarenakan tanah gambut merupakan hasil dari bahan organik yang telah melapuk maupun yang masih mentah atau yang belum melapuk sempurna dalam kurun waktu yang sangat lama. Bahan organik yang belum melapuk dengan sempurna ini melakukan respirasi setiap waktunya dengan mengeluarkan ion $\mathrm{H}^{+}$ke dalam tanah sehingga tanah menjadi masam (Hardjowigeno, 2003).

Bakteri yang tumbuh pada cawan petri dihitung menggunakan colony counter. Diperoleh jumlah populasi bakteri sebanyak $1,06 \times 10^{6} \mathrm{CFU} / \mathrm{g}$ tanah, yang diambil pada kedalaman $\quad 0-20 \mathrm{~cm}$ karena termasuk ke dalam zona yang memiliki kandungan bahan organik yang banyak dan berada pada daerah perakaran, dimana akar tanaman merupakan habitat yang baik bagi pertumbuhan mikroorganisme, hal ini sesuai dengan pernyataan Winarso (2005) mikroorganisme di dalam tanah banyak ditemukan di daerah perakaran (Rhizosphere). Menurut Ardi (2009) tingginya populasi bakteri di permukaan tanah disebabkan oleh sistem perakaran tumbuhan yang memungkinkan menyediakan substrat dan suplai makanan sehingga metabolit akar tanaman akan meningkatkan nutrisi di dalam tanah yang berpengaruh terhadap populasi bakteri tanah. Oleh karena itu mikroorganisme lebih banyak berada pada lapisan tanah yang paling atas.

Hasil karakterisasi didapatkan 5 koloni yang memiliki morfologi makroskopis bakteri yang berbeda berdasarkan morfologi bakteri, yakni bentuk koloni, elevasi koloni, permukaan koloni dan warna koloni, hasil karakterisasi makroskopis dapat dilihat pada Tabel 2.

Tabel 2. Morfologi Koloni Bakteri PGPR di Media NA

\begin{tabular}{clccl}
\hline $\begin{array}{c}\text { Kode } \\
\text { Isolat }\end{array}$ & Bentuk Koloni & Elevasi & Permukaan & Warna Koloni \\
\hline KS1 & Bulat & Koloni & Koloni & \\
KS2 & Bulat dengan tepi bergelombang & Lobat & Timbul & Timbul \\
KS3 & Bulat & Halus & Timbul & Putih kekuningan \\
KS4 & Konsentrik & Halus & Datar & Putih kekuningan \\
KS5 & Bulat dengan tepi timbul & Halus & Timbul & Putih susu \\
\hline
\end{tabular}

Berdasarkan hasil pengamatan pewarnaan gram dan uji biokimia, identifikasi bakteri PGPR dilakukan hingga ke tingkat spesies. Terdapat lima isolat bakteri yang 
berhasil diidentifikasi dengan mencocokkan karakter isolat yang diperoleh berdasarkan buku panduan Bergey's Manual of Determinative Bacteriology. Kelima isolat yang berhasil diidentifikasi memiliki genus yang sama yaitu Bacillus. Hasil pewarnaan gram dan uji biokimia dapat dilihat pada Tabel 3 .

Tabel 3. Hasil Pengamatan Uji Reaksi Biokimia

\begin{tabular}{|c|c|c|c|c|c|}
\hline \multirow{2}{*}{ Uji Biokimia } & \multicolumn{5}{|c|}{ Kode Isolat } \\
\hline & KS1 & KS2 & KS3 & KS4 & KS5 \\
\hline Pewarnaan Gram & + & + & + & + & + \\
\hline Katalase & + & + & + & + & + \\
\hline Oksidase & - & - & - & - & - \\
\hline Motilitas & + & + & + & - & - \\
\hline Glukosa & - & - & - & - & + \\
\hline Genus & Bacillus sp 1 & Bacillus sp 2 & Bacillus sp 3 & Bacillus sp 4 & Bacillus sp 5 \\
\hline
\end{tabular}

Bacillus sp. merupakan bakteri berbentuk batang, tergolong bakteri gram positif pada kultur muda, motil (reaksi nonmotil kadang terjadi), menghasilkan spora yang biasanya resisten pada panas, bersifat aerob (beberapa spesies bersifat anaerob fakultatif), katalase positif, dan oksidasi bervariasi. Tiap spesies berbeda dalam penggunaan gula, sebagian melakukan fermentasi dan sebagian tidak.Secara alami sering ditemukan ditanah dan vegetasi (Schaechter, 2009).

Bacillus sp. mampu menghasilkan struktur khusus endospora sebagai pertahanan diri yang mengaktifkan organisme untuk bertahan pada kondisi yang tidak menguntungkan, yaitu suhu ekstrim, kekeringan, dan kekurangan nutrisi beberapa spesies dari genus Bacillus berperan sebagai pestisida, fungisida, biofertilizer, dan memiliki kemampuan memacu pertumbuhan tanaman (Madigan et al., 2012).

Bacillus sp. juga merupakan bakteri aerob dan anaerob fakultatif. Kemampuan Bacillus sp. dalam membentuk endospora sangat menguntungkan bagi bakteri tanah terkait dengan habitatnya yang selalu berubah dan tidak menguntungkan, selain itu nilai tambah dari Bacillus sp. yaitu mampu memproduksi IAA (Indol Asam Asetat) sehingga meningkatkan bobot basah akar, melarutkan fosfat dan sebagai agen biokontrol dengan menginduksi sistem kekebalan tanaman (Marista dkk., 2013).

Menurut Eliza (2004) dan Sutariati (2006), bakteri Bacillus sp. dan Pseudomonas sp. mempunyai kemampuan sebagai antagonis, penghasil hormon pertumbuhan, pelarut phospat, penambat nitrogen, sekresi enzim (kitinase, protease, selulose), memproduksi hidrogen sianida.

Uji Produksi IAA secara kualitatif. Kemampuan mikroba dalam menghasilkan IAA dipengaruhi oleh spesies. Tidak semua mikroba dari spesies yang sama mampu menghasilkan IAA yang sama pula. Semakin pekat warna merah yang dihasilkan mengindikasikan semakin tinggi produksi IAA yang dihasilkan. Hasil uji analisis secara kualitatif dapat dilihat pada Gambar 2 di bawah ini.
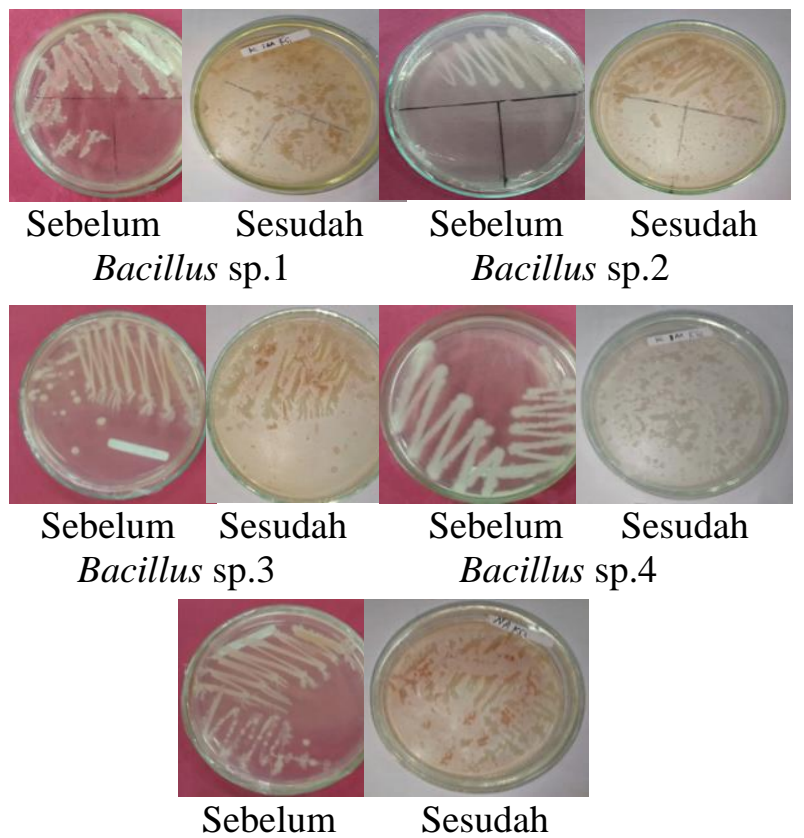

Bacillus sp 5

Gambar 2. Hasil Uji IAA Secara Kualitatif

Hasil analis uji IAA secara kualitatif pada ke 5 isolat bakteri menunjukan bahwa, 
isolat Bacillus sp.1 Bacillus sp. 2 Bacillus sp. 3 dan Bacillus sp. 5 menunjukkan warna merah muda pada media. Hal ini menunjukkan bahwa isolat-isolat tersebut berpotensi untuk memproduksi hormon IAA. Hanya satu yaitu Bacillus sp.4 yang tidak mampu memproduksi hormon IAA. Menurut Kovacs (2009) Indole3 -acetic acid (IAA) berikatan dengan $\mathrm{FeCl}_{3}$ dan $\mathrm{HClO}_{4}$ yang merupakan senyawa penyusun pereaksi Salkoswki membentuk kompleks tris(indole-3-aceto) iron (III) yang memberikan warna merah muda.

Agustian dkk., (2010) menyatakan bahwa produksi IAA sangat dipengaruhi oleh tingkat pertumbuhan dan ketersediaan substrat Ltriptofan dalam media. Hal ini menunjukkan bahwa penambahan L-triptofan pada media pertumbuhan merupakan faktor penting isolat bakteri untuk biosintesis IAA. Bakteri penghasil IAA pada tanaman dengan kondisi dan bagian yang berbeda maka akan bervariasi baik jenis ataupun kemampuannya (Herlina dkk., 2016). Menurut Sutariati (2006) Isolat Bacillus spp. dan $P$. fluorescens dilaporkan mampu menghasilkan hormon IAA.

Uji Pelarutan Fosfat. Kemampuan isolat dalam melarutkan fosfat dapat dilihat dari terbentuknya zona bening pada medium selektif Pikovskaya. Terbentuknya zona bening di sekitar koloni menunjukkan bahwa isolat tersebut mampu menghasilkan asam organik ekstraseluler yang mampu berikatan dengan ion $\mathrm{Ca}^{+}$yang terikat dalam bentuk $\mathrm{Ca} 3(\mathrm{PO} 4) 2$ pada media Pikovskaya agar dan membebaskan ion $\mathrm{H}_{2} \mathrm{PO}_{4}$ sehingga membentuk area yang berwarna lebih jernih dari pada area yang masih memiliki P terikat (Saragih, 2013).

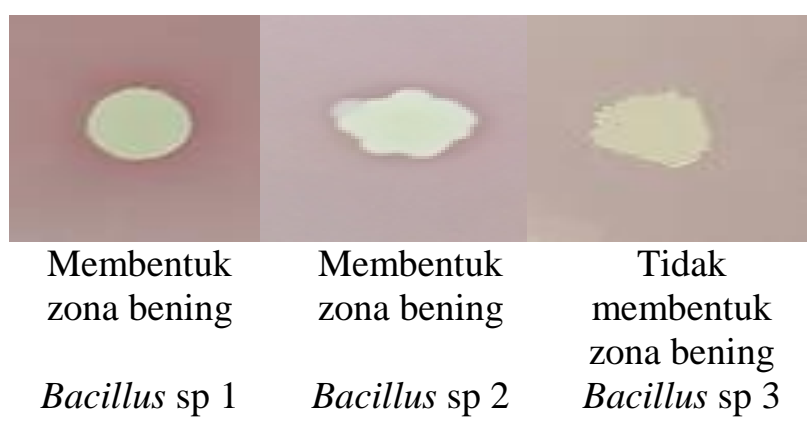

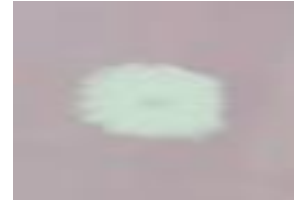

Tidak membentuk zona bening Bacillus sp 4

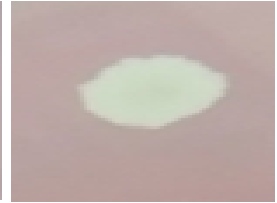

Tidak membentuk zona bening Bacillus sp 5

\section{Gambar 3. Hasil Uji Pelarut Fosfat}

Isolat yang mampu membentuk zona bening kemudian dilakukan pengukuran zona bening setelah diinkubasi selama tujuh hari pada suhu $37 \quad{ }^{\circ} \mathrm{C}$ kemudian dihitung menggunakan rumus indeks kelarutan fosfat.

Tabel 4. Hasil Pengukuran Indeks Kelarutan Fosfat

\begin{tabular}{lcccc}
\hline \multicolumn{1}{c}{ Nama Isolat } & Diameter Total $(\mathrm{mm})$ & Diameter Koloni $(\mathrm{mm})$ & Nilai IKF $(\mathrm{mm})$ & Kriteria IKF \\
\hline Bacillus $\mathrm{sp}$ & 13,0 & 8,0 & 1,62 & Sedang \\
Bacillus sp 2 & 11,0 & 7,0 & 1,57 & Rendah \\
Bacillus sp 3 & 8,0 & 8,0 & 1,00 & Rendah \\
Bacillus sp 4 & 8,4 & 8,4 & 1,00 & Rendah \\
Bacillus sp 5 & 8,6 & 8,6 & 1,00 & Rendah \\
\hline
\end{tabular}

Saragih (2013) dan Mursyida (2015) menyebutkan bahwa ukuran koloni tidak selalu berpengaruh terhadap terbentuknya zona bening disekitar koloni tersebut, karena ukuran diameter koloni yang besar belum tentu menghasilkan zona bening yang besar pula. Meskipun luas zona bening dapat menunjukkan kemampuan relatif dalam melarutkan $\mathrm{P}$, tetapi tidak dapat menunjukkan jumlah (konsentrasi) $\mathrm{P}$ yang terlarut di dalam medium.Sesuai dengan hasil penelitian yang dilakukan oleh Widawati dan Suliasih (2006) bahwa isolat yang membentuk zona bening lebih cepat dan nilai IKF luas merupakan bakteri pelarut fosfat yang berpotensi sebagai "biofertilizer" serta menyatakan bahwa bakteri Bacillus sp.merupakan bakteri pelarut fosfat yang memiliki kemampuan terbesar sebagai "biofertilizer" dengan cara 
melarutkan unsur fosfat yang terikat pada unsur lain ( $\mathrm{Fe}, \mathrm{Al}, \mathrm{Ca}$ dan $\mathrm{Mg}$ ) sehingga unsur $\mathrm{P}$ menjadi tersedia.

Uji daya hambat secara In-vitro. Kemampuan isolat dalam menghambat patogen ditunjukan oleh terhambatnya pertumbuhan bagian jari-jari koloni patogen yang mengarah ke isolat mengalami penghambatan pertumbuhan. Isolat yang mampu menghasilkan daya hambat yaitu isolat Bacillus sp.4 dengan persentase daya hambat 33,33\% dan Bacillus sp.5 dengan persentase daya hambat $17,24 \%$, sedangkan isolat Bacillus sp.1 Bacillus sp.2 Bacillus sp.3 tidak menghasilkan daya hambat.

Shehata et al. (2008) menyatakan bahwa sifat mikroorganisme antagonis adalah pertumbuhannya lebih cepat dibanding dengan patogen dan atau menghasilkan senyawa antibiotik yang dapat menghambat pertumbuhan patogen

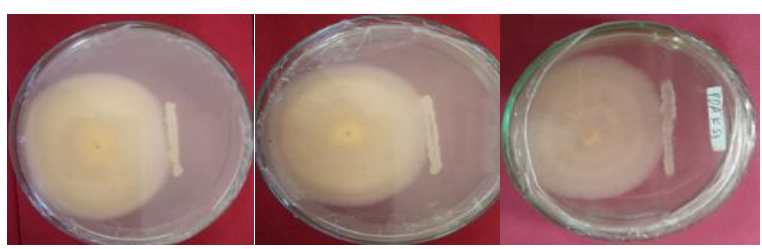

$$
\text { Bacillus sp1 Bacillus sp } 2 \quad \text { Bacillus sp } 3
$$

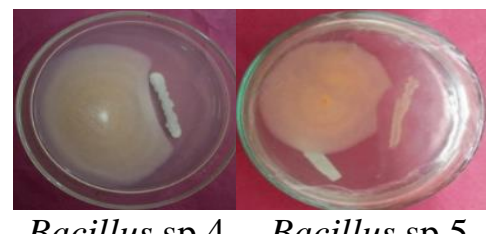

Gambar 4. Hasil Uji daya Hambat Secara In-vitro

Tabel 5. Hasil Uji Aktifitas Biologi Bakteri PGPR

\begin{tabular}{lccc}
\hline \multirow{2}{*}{ Nama Isolat } & \multicolumn{3}{c}{ Aktifitas Biologi } \\
\cline { 2 - 4 } & IAA & BPF & Daya Hambat \\
\hline Bacillus sp.1 & + & + & - \\
Bacillus sp.2 & + & + & - \\
Bacillus sp.3 & + & - & + \\
Bacillus sp.4 & - & - & + \\
Bacillus sp.5 & + & - & \\
\hline
\end{tabular}

Keterangan: (+) Positif; (-) Negatif;

\section{KESIMPULAN}

Jumlah populasi bakteri PGPR yang didapat yaitu $1,06 \times 10^{6} \mathrm{CFU} / \mathrm{g}$ tanah dan hasil identifikasi 5 isolat bakteri PGPR yang ditemukan, yaitu genus bakteri Bacillus sp.1, Bacillus sp 2, Bacillus sp 3, Bacillus sp 4 dan Bacillus sp.5. dan bakteri PGPR yang diisolasi dari kebun karet rakyat memiliki aktifitas biologi yang berbeda. Sebanyak 4 isolat mampu menghasilkan hormon IAA yaitu Bacillus sp 1, Bacillus sp 2, Bacillus sp 3 dan Bacillus sp 5. Sebanyak 2 isolat mampu melarutkan fostat yaitu Bacillus sp. 1 dan Bacillus sp 2 dan sebanyak 2 isolat mampu berperan sebagai daya hambat terhadap cendawan Fusarium sp yaitu Bacillus sp 4 dan Bacillus sp 5.

\section{DAFTAR PUSTAKA}

Agustian, Nuriyani, L. Maira dan O. Emalinda. 2010. Rhizobakteria Penghasil Fitohormon IAA pada Rhizosfir Tumbuhan Semak Karamunting, Titonia, dan Tanaman Pangan. Jurnal Solum, 7 (1): 49-60.

Ardi, R. 2009. Kajian Aktivitas Mikroorganisme Tanah pada Berbagai Kelerengan dan Kedalaman Hutan Taman Nasional Gunung Leuser.Skripsi. Fakultas Pertanian Universitas Sumatera Utara. Medan.

Aryantha, I.N.Y.P., P.L. Dian. dan P.D.P. Nurmi. 2004. Potensi Isolat Bakteri Penghasil IAA dalam Peningkatan Pertumbuhan Kecambah Kacang Hijau pada Kondisi Hidroponik. Jurnal Mikrobiologi Indonesia, 9: 43-46. 
Eliza. 2004. Pengendalian Layu Fusarium pada Pisang dengan Bakteri Perakaran Graminae. Tesis. Institut Pertanian Bogor. Bogor.

Hardjowigeno, H.S. 2003. Ilmu Tanah. Akademika Pressindo. Jakarta. 233 hal.

Herlina, L.K.K., Pukan. dan D. Mustikaningtyas. 2016. Kajian Bakteri Endofit Penghasil IAA (Indole Acetic Acid) untuk Pertumbuhan Tanaman. Jurnal Sains dan Teknologi,14 (1): 115-119.

Jobsi, L. 2001. Pengetahuan Ekologi. InProssiding, 11-30.

Kafrawi, Z. S. Kumalawati dan Muliani. 2015. Skrining Isolat Plant Growth Promoting Rhizobacteri (PGPR) dari Pertanaman Bawang Merah (Allium ascalonicum) di Gorontalo. Prosiding Seminar Nasional Mikrobiologi Kesehatan dan Lingkungan, 132-139.

Karpagam, T., and P.K. Nagalakshmi. 2014. Isolation and Characterization of Phosphate Solubilizing Microbes from Agricultural Soil. Jurnal of Current Microbiology and Applied Sciences, 3 (3): 601-614.

Khalida, F.T dan E. Zulaika. 2015. Potensi Azotobacter sebagai Penghasil Hormon IAA(Indole-3-Acetic Acid). Jurnal Sains dan Seni Its, 4 (2): 75-77

Kovacs, K. 2009. Applications of Mossbauer Spectroscopy in Plant Physiology. Disertasi. ELTE Chemistry Doctoral School, ELTE Institute of Chemistry, Budapest.

Madigan, M.T., J. Martinko., D.A. Stahl. and D.P. Clark. 2012. Brock Biology of Microorganisms. San Fransisco. Benjamin Cummings.

Marista, E., S. Khotimah, dan R. Linda, 2013. Bakteri Pelarut Fosfat Hasil Isolasi dari Tiga Jenis Tanah Rizosfer Tanaman Pisang Nipah (Musa paradisiaca varr. Nipah) di Kota Sengkawang. Jurnal Protobiont, 2 (2): 93-101.

Mursyida, E. 2015. Isolasi dan Identifikasi Bakteri Pelarut Fosfat dan Kalium dari Kawasan Sekitar Tambang Batu Kapur Cirebon. Tesis. Institut Pertanian Bogor. Bogor.

Niswati, A., S. Yusnaini dan M.A.S. Arif. 2008. Populasi Mikroba Pelarut Fosfat dan P Tersedia pada Rizosfer Beberapa Umur dan Jarak dari Pusat Perakaran Jagung (Zea mays L.). Jurnal Tanah Trop, 13 (2): 123-130.

Ruwandani, M.N. Rakhmawati, A. dan E. Yulianti. 2014. Isolasi, Karakterisasi, dan Identifikasi Bakteri Pelarut Fosfat dari Guano di Gua Anjani, Jawa Tengah. Fakultas Matematika dan Ilmu Pengetahuan Alam Universitas Negeri Yogyakarta. Yogyakarta.

Saragih, A.B. 2013. Skrining Bakteri Pelarut Fosfat Adaptif Vinasse dari Lahan Tebu Pabrik Gula Jatiroto Kabupaten Lumajang Jawa Timur. Skripsi. Fakultas Matematika dan Ilmu Pengetahuan Alam Universitas Jember. Jember.

Saraswati, R dan Sumarno. 2008. Pemanfaatan Mikroba Penyubur Tanah sebagai Komponen Teknologi Pertanian. Iptek Tanaman Pangan, 3 (1): 41-58.

Saraswati, R., E. Husen dan R.D.M. Simanungkalit. 2007. Metode Analisis Biologi Tanah. Balai Besar Penelitian dan Pengembangan Sumberdaya Lahan Pertanian. Jawa Barat. 271 hal.

Schaechter, M. 2009. Encyclopedia of Mikrobiology. Third Edition. Elsevier Inc. USA. $460 \mathrm{p}$.

Shehata, S. Fawzy. and A.M. Borollosy. 2008. Induction of Resistance Against Zuccini Yellow Mosaic Potyvirus and Growth Enhancement of Squash Plants Using Some Plant Growth Promoting Rhizobacteria. Australian Journal of Basic and Applied Scienes. 2: 174-182.

Sumarsih, S. 2003. Mikrobiologi Dasar. Diktat Kuliah. Fakultas Pertanian UPN Veteran. Yogyakarta. 116 hal.

Sutariati, G.A.K, Widodo, Sudarsono dan S. Ilyas. 2006. Pengaruh Perlakuan Rhizobakteri Pemacu Pertumbuhan Tanaman Terhadap Viabilitas Benih Serta Pertumbuhan Bibit Tanaman Cabai. Bul Agron, 34 (1): 46-54.

Widawati, S. dan Sulasih. 2006. Populasi Bakteri Pelarut Fosfat (BPF) di Cikaniki, Gunung Botol, dan Ciptaras, Serta Kemampuannya Melarutkan P Terikat di Media Pikovskaya Padat. Biodiversitas,7 (2): 109-113.

Winarso, S. 2005. Kesuburan Tanah Dasar Kesehatan dan Kualitas Tanah. Gava Media. Yogyakarta. 269 hal. 